\title{
Analisis Kandungan Zat Gizi Tepung Tulang Ikan Sidat (Anguila sp)
}

\author{
Ahmil $^{* 1}$, Hepti Muliyati ${ }^{2}$, Opyn Mananta ${ }^{3}$ \\ ${ }^{1}$ Program Studi Keperawatan, Sekolah Tinggi Ilmu Kesehatan Widya Nusantara Palu, Indonesia \\ ${ }^{2}$ Program Studi Gizi, Sekolah Tinggi Ilmu Kesehatan Widya Nusantara Palu, Indonesia \\ ${ }^{3}$ Penanggung jawab Program Schistosomiasis, Dinas Kesehatan Kabupaten Poso, Indonesia
}

Author's Email Correspondence (*): ahmil@stikeswnpalu.ac.id

\begin{abstract}
Abstrak
Pemanfaatan limbah tulang ikan salah satunya adalah dibuat tepung. Pengolahan dalam bentuk tepung bertujuan untuk memperpanjang daya awet dan daya simpan. Tepung ikan dapat ditambahkan pada produk ekstrusi, roti, biskuit dan kue kering. Namun pemanfaat tepung tulang ikan sidat menjadi bahan pangan masih sangat kurang. Oleh karena itu, perlunya dilakukan penelitian pendahuluan terkait analisis kandungan gizi pada tepung tulang ikan sidat tersebut. Penelitian ini dilakukan dalam dua tahapan, yaitu tahap pembuatan tepung dan tahap analisis zat gizi. Analisis zat gizi dilakukan di Laboratorium Saraswanti Indo Genetech (SIG) Bogor meliputi Kadar abu dianalisis dengan metode SNI 01-2891-1992, 6.1; kadar air dianalisis dengan metode SNI 01-2891-1992, poin 5.1; protein dianalisis dengan metode 18-8-31/MU/SMM-SIG (Kjeltec); lemak total dianalisis dengan metode 18-8-5/MU/SMM-SIG (Weilbull); energi dari lemak dianalisis dengan metode kalkulasi; energi total dianalisis dengan metode kalkulasi; karbohidrat dianalisis dengan metode 18-8-9/MU/SMM-SIG; Besi dianalisis dengan metode 18-13-1/MU/SMM-SIG (ICP OES), Seng dianalisis dengan metode 18-13-1/MU/SMM-SIG (ICP OES); Kalsium dianalisis dengan metode 18-13-1/MU/SMM-SIG (ICP OES). Hasil penelitian menunjukkan bahwa tepung tulan ikan sidat menandung kadar abu $44.14 \%$, kadar air $5.98 \%$, protein $34.08 \%$, lemak total $9.14 \%$, karbohidrat $6.66 \%$, besi $20.45 \mathrm{mg} / 100 \mathrm{~g}$, seng $10.34 \mathrm{mg} / 100 \mathrm{~g}$, dan kalsium 18325.13 $\mathrm{mg} / 100 \mathrm{~g}$. Kesimpulannya tepung tulang ikan sidat mengandung kadar abu, protein, dan kalsium yang sangat tinggi dibandingkan zat gizi lainnya.
\end{abstract}

Kata Kunci: Zat gizi, Tepung, Tulang, Ikan sidat

How to Cite:

Muliyati, H., Ahmil, A., \& Mananta, O. (2021). Analisis Kandungan Zat Gizi Tepung Tulang Ikan Sidat (Anguila sp). Ghidza: Jurnal Gizi Dan Kesehatan, 5(1), 34 - 42. https://doi.org/10.22487/ghidza.v5i1.138

\section{Published by:}

Tadulako University

Address:

Soekarno Hatta KM 9. Kota Palu, Sulawesi Tengah, Indonesia.

Phone: +628525357076

Email: ghidzajurnal@gmail.com
Article history :

Received : 11092020

Received in revised form : 29012021

Accepted : 30012021

Available online 02072021 


\begin{abstract}
Fishbone waste could be utilized to fishbone flour. The purpose of this utilization was to prolong durability and storability of fishbone. Fishbone flour can be added to extrusion product, bread, biscuit, and cookies. But, the utilization of Sidat fishbone into flour is still lacking. Therefore, preliminary study to analyzed nutrient composition in Sidat bone flour need to be done. This study consists of two steps, the first step is flour making from Sidat fishbone and the second is nutrient composition analysis. Nutrient composition was analyzed in Saraswanti Indo Genetech (SIG) Laboratory, Bogor, including ash content which analyzed by SNI Method No. 01-2891-1992, 6.1; moisture content analyzed by SNI Method No. 01-2891-1992, poin 5.1; protein content analyzed by 18-8-31/MU/SMM-SIG method (Kjeltec); total fat analyzed by $18-8-5 / \mathrm{MU} / \mathrm{SMM}$-SIG method (Weilbull); energy from total fat and total energy analyzed by calculation method; carbohydrate content analyzed by 18-8-9/MU/SMM-SIG method; iron analyzed by 18-13-1/MU/SMM-SIG method (ICP OES); zinc analyzed by 18-13-1/MU/SMM-SIG method (ICP OES); and calcium analyzed by 18-13-1/MU/SMM-SIG method (ICP OES). The result showed that Sidat bone flour contained $44.14 \%$ ash content, $5.98 \%$ moisture content, $34.08 \%$ protein content, $9.14 \%$ crude fat, and $6.66 \%$ carbohydrate content. Mineral composition contained in 100 gram Sidat fishbone flour were $20.45 \mathrm{mg}$ iron, $10.34 \mathrm{mg}$ zinc, dan $18325.13 \mathrm{mg}$ calcium. The result showed that Sidat fishbone flour contained higher ash, protein and calcium content than other nutrition content.
\end{abstract}

Keywords: Nutrient content, Flour, Fishbone, Sidat fish

\title{
I. PENDAHULUAN
}

Sumberdaya perikanan di Indonesia memiliki potensi yang besar, baik dari perikanan tangkap maupun hasil budidaya. Potensi perikanan di Indonesia memiliki jumlah mencapai 12541438 ton, dengan estimasi pemanfaatan yang berbeda tergantung dari jenis ikan serta lokasi penangkapannya (KKP, 2017). Produktivitas perikanan yang cukup besar ini menyebabkan tingginya hasil limbah yang dihasilkan. Limbah yang dihasilkan dari industri pengolahan ikan yaitu berkisar diantara 20-30\% dengan total limbah setiap tahun mencapai 3,6 juta ton (KKP, 2007).

Industri pengolahan perikanan yang berkembang saat ini di Indonesia salah satunya yaitu industri olahan ikan sidat. Jenis bahan baku ikan sidat (Anguilla bicolor) memiliki nilai jual tinggi karena pada umumnya telah diekspor ke berbagai negara terutama di negara Asia yaitu negara Jepang. Produksi ikan sidat secara global pada tahun 2010 mencapai 8440 ton dengan nilai jual sebesar 36 juta US\$ (FAO, 2010)

Pada industri pengolahan maupun pemanfaatan ikan oleh rumah tangga, bagian ikan yang dibuang dan menjadi limbah adalah kepala, ekor sirip, tulang dan jeroan dengan menghasilkan ikan yang telah disiangi rata-rata sebesar 65\%, sehingga meninggalkan limbah perikanan sebesar 35\% (Irawan, 1995); (Ramdany et al., 2006). Limbah ini bila tidak ditangani dengan baik akan menyebabkan pencemaran lingkungan. Sedangkan, tulang ikan merupakan komponen yang keras dalam tubuh ikan sehingga, penguraiannya membutuhkan waktu yang lama.

Dibutuhkan cara yang tepat dalam menangani masalah limbah ini tanpa mengeluarkan biaya yang terlalu besar atau dapat menjadikan pemasukan tersendiri sehingga dapat menghindari terjadinya pencemaran lingkungan. Menurut (Fitri et al., 2016) bagian tubuh ikan yang jarang dikonsumi adalah pada kepala ikan sebesar 18\%, kulit ikan sebesar 4\%, tulang ikan sebesar 8\%. Padahal, limbah yang 
terdapat pada ikan seperti tulang, kepala dan ekor dapat diolah kembali dan memiliki nilai gizi tambah pada produk olahan makanan yaitu kalsium (Sari, 2013).

Tulang merupakan salah satu bentuk limbah yang dihasilkan dari industri pengolahan ikan yang memiliki kandungan kalsium terbanyak dalam tubuh ikan. Dari sudut pandang pangan dan gizi, tulang ikan sangat kaya akan kalsium yang dibutuhkan manusia, karena unsur utama dari tulang ikan adalah kalsium, fosfor dan karbonat. Dengan demikian limbah tulang ikan mempunyai potensi yang besar untuk dimanfaatkan sebagai bahan baku tepung tulang ikan yang kaya kalsium. Tulang ikan banyak mengandung garam mineral seperti kalsium fosfat dan kreatin fosfat yang berpotensi untuk meningkatkan nutrisi produk pangan (Maulida, 2005).

Pemanfaatan limbah tulang ikan salah satunya adalah dibuat tepung. Tepung tulang ikan adalah suatu produk padat kering yang dihasilkan dengan cara mengeluarkan sebagian besar cairan atau seluruh lemak yang terkandung pada tulang ikan (Kaup et al., 1991 dalam (Kaya, 2008). Pengolahan dalam bentuk tepung bertujuan untuk memperpanjang daya awet dan daya simpan. Tepung ikan dapat ditambahkan pada produk ekstrusi, roti, biskuit dan kue kering (Wardani et al., 2012).

Pemanfaat tepung tulang ikan sidat menjadi bahan pangan masih sangat kurang. Oleh karena itu, perlunya dilakukan penelitian pendahuluan terkait analisis kandungan gizi pada tepung tulang ikan sidat tersebut.

\section{METODE}

Bahan yang digunakan dalam penelitian ini yaitu tulang ikan sidat (Anguila sp) yang berasal dari Kabupaten Poso. Bahan lain yang digunakan adalah bahan analisis seperti aquadest, aquabidest, air, heksan, $\mathrm{H} 2 \mathrm{SO} 4$ pekat, $\mathrm{HCl}, \mathrm{HNO} 3, \mathrm{CuSO} 4, \mathrm{KMnO} 4$, dan $\mathrm{NaOH}$.

Alat-alat yang digunakan dalam penelitian ini adalah baskom plastik, sarung tangan, panci stainless, kompor gas, chopper, timbangan analitik, cawan porselen, muffle furnace, oven, ICP OES, autoklaf, tanur, desikator, spektrofotometer UV-Vis, water bath, destilator dan kondensor, hot plate, labu ukur, gelas beker, gelas ukur, tabung kjeltec, tabung reaksi, erlenmeyer, digestion block, sudip, gegep, corong, ayakan ukuran 70 mesh, mortal, gegep, kaca arloji, blender, kertas saring Whatman 42, wadah kedap udara, alumunium foil, batang pengaduk, pipet volumetri, dan pipet tetes.

Penelitian ini dilakukan dalam dua tahapan, yaitu tahap pembuatan tepung dan tahap analisis zat gizi. Pembuatan tepung tulang ikan dimulai dari sortasi ikan, kemudian pemisahan antara tulang dan daging ikan, pencucian, perebusan tulang ikan, pembersihan tulang ikan dari daging yang masih menempel, pengeringan dengan oven (suhu 1000C) selama 1 jam, dan penghalusan dengan mortar. Setelah dilakukan penghalusan, tulang harus disoxhletasi. Hal ini dilakukan karena tulang mengandung lemak yang cukup banyak sehingga sulit untuk menjadi tepung.

Analisis zat gizi dilakukan di Laboratorium Saraswanti Indo Genetech (SIG) Bogor meliputi Kadar abu dianalisis dengan metode SNI 01-2891-1992, 6.1; kadar air dianalisis dengan metode SNI 01-28911992, poin 5.1; protein dianalisis dengan metode 18-8-31/MU/SMM-SIG (Kjeltec); lemak total dianalisis 
dengan metode 18-8-5/MU/SMM-SIG (Weilbull); energi dari lemak dianalisis dengan metode kalkulasi; energi total dianalisis dengan metode kalkulasi; karbohidrat dianalisis dengan metode 18-8-9/MU/SMMSIG; Besi dianalisis dengan metode 18-13-1/MU/SMM-SIG (ICP OES), Seng dianalisis dengan metode 18-13-1/MU/SMM-SIG (ICP OES); Kalsium dianalisis dengan metode 18-13-1/MU/SMM-SIG (ICP OES).

\section{HASIL}

Ikan sidat yang digunakan pada adalah spesies Anguila marmorata yang berasal dari Kabupaten Poso dan dikenal dengan sebutan sogili (Gambar 1). Pada penelitian ini digunakan limbah ikan sidat berupa tulang untuk diolah menjadi tepung (Gambar 2).

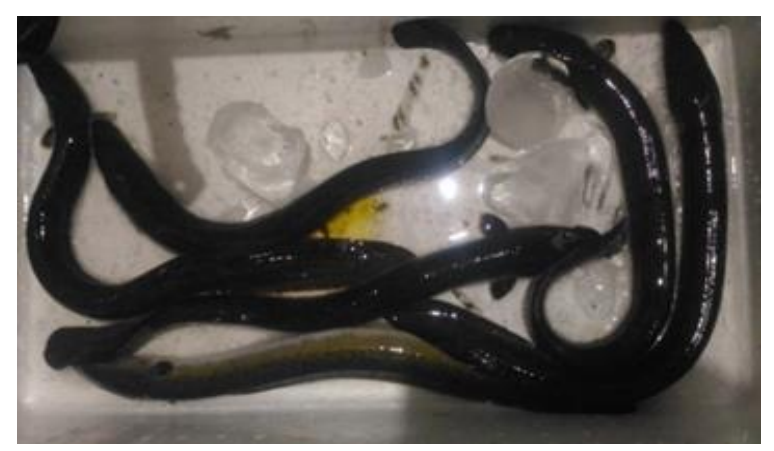

Gambar 1. Ikan Sidat

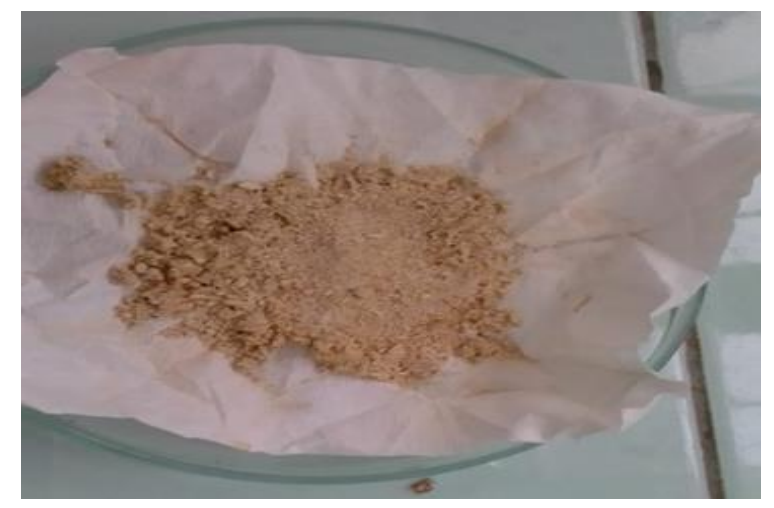

Gambar 2. Tepung Tulang Ikan Sidat 
Analisis zat gizi yang dilakukan terdiri dari analisis proksimat dan analisis mineral seperti terlihat pada Tabel 1.

Table 1 Hasil Uji Zat Gizi Tepung Tulang Ikan Sidat (Anguila sp)

\begin{tabular}{lcc}
\hline Parameter & Satuan & Hasil \\
\hline Analisis Proksimat & $\%$ & 44.14 \\
Kadar abu & $\%$ & 5.98 \\
Kadar air & $\%$ & 34.08 \\
Protein & $\%$ & 9.14 \\
Lemak total & $\%$ & 6.66 \\
Karbohidrat & $\mathrm{kkal} / 100 \mathrm{~g}$ & 82.26 \\
Energi dari lemak & $\mathrm{kkal} / 100 \mathrm{~g}$ & 245.22 \\
Energi total & & \\
\hline Analisis Mineral & $\mathrm{mg} / 100 \mathrm{~g}$ & 20.45 \\
Besi & $\mathrm{mg} / 100 \mathrm{~g}$ & 10.34 \\
Seng & $\mathrm{mg} / 100 \mathrm{~g}$ & 18325.13 \\
Kalsium & & \\
\hline
\end{tabular}

Tabel 1 menunjukkan bahwa berdasarkan hasil analisis proksimat, kadar abu memiliki nilai yang paling besar dibandingkan zat gizi lainnya yaitu $44.14 \%$. Tingginya kadar abu mengindikasikan bahwa kadar mineral dalam bahan juga lebih tinggi. Hasil analisis mineral kalsium pada tepung tulang ikan memiliki jumlah yang sangat tinggi dibandingkan besi dan seng yaitu $18325.13 \mathrm{mg} / 100 \mathrm{~g}$.

\section{PEMBAHASAN}

Tepung tulang ikan sidat yang dihasilkan pada penelitian ini selanjutnya akan diolah menjadi crackers untuk anak sekolah penderita schistosomiasis. Kadar abu yang dihasilkan dari tepung tulang ikan sidat sebesar 44.14\% lebih tinggi dibandingkan kadar abu tepung tulang produksi (ISA, 2002) yaitu $33.1 \%$, tetapi lebih rendah dibandingkan kadar abu tepung tulang ikan belida pada penelitian (Kusumaningrum et al., 2016)yang berkisar 76.79\%-83.94\% dan kadar abu tepung tulang ikan nila sebesar 75\% (Hemung, 2013) serta kadar abu tepung tulang ikan patin sebesar 63.5\% (Mulia, 2004). Kadar abu tepung tulang dari beberapa spesies ikan dapat lebih dari $40 \%$ (Toppe et al., 2007). Mayoritas kadungan tepung tulang ikan pada penelitian ini adalah kadar abu. Perbandingan kadar abu dan kadar protein merupakan kriteria penting untuk menunjukkan mineralisasi tulang yang berkaitan dengan tingkat kekerasan tulang (Kusumaningrum et al., 2016). Tingginya kadar abu disebabkan karena komponenen penyusun tulang yang utama adalah mineral. Di dalam tulang terkandung sel-sel hidup dan matrik intraseluler dalam bentuk garam mineral. Garam mineral merupakan komponen yang terdiri dari kalsium fosfat sebanyak 80\% dan sisa terdiri dari kalsium karbonat dan magnesium fosfat (Frandson, 1992 dalam (Tababaka, 2004).

Kadar air tepung tulang ikan sidat sebesar 5.98\% (Tabel 1). Kadar air ini lebih tinggi dibandingkan kadar air tepung tulang produksi ISA (2002) yaitu 3.6\%. Hal ini dimungkinkan karena penggunaan metode pembuatan tepung yang berbeda. Kadar air merupakan banyaknya air yang terkandung dalam bahan pangan yang dinyatakan dalam persen. Kadar air juga merupakan salah satu 
karakteristik yang sangat penting pada bahan pangan karena dapat mempengaruhi penampakan, tekstur dan cita rasa bahan pangan. Kadar air dalam bahan pangan ikut menentukan kesegaran dan daya awet bahan pangan tersebut (Winarno, 2008).

Kadar protein tepung tulang ikan sidat pada penelitian ini sangat tinggi yaitu $34.08 \%$ dibandingkan kadar protein tepung tulang ikan lainnya seperti tulang ikan belida berkisar antara 9.87\% 15.18\% (Kusumaningrum et al., 2016), tulang ikan patin sebesar 33.50\% (Aprilliani, 2010). Hal ini dapat disebabkan oleh perbedaan prosedur preparasi. Penelitian ini dilakukan hanya direbus menggunakan air panas sedangkan pada penelitian lainnya menggunakan larutan basa panas. Protein yang terdapat dalam tulang pada umumnya dikategorikan ke dalam protein stroma. Protein stroma ini tahan terhadap larutan asam maupun larutan basa ( $\mathrm{Li}$ et al., 2013). Kadar protein dalam tulang ikan meningkat sejalan dengan pertumbuhan (Hemung, 2013). Protein sangat berperan dalam penyerapan kalsium melalui peran protein pengikat kalsium yaitu asam amino lisin dan argin (Harland \& Oberleas, 2001).

Kadar lemak yang dihasilkan tepung tulang ikan sidat sebesar 9.14\% (Tabel 1). Nilai tersebut lebih besar dibandingkan kadar lemak tepung tulang produksi (ISA, 2002) yaitu 5,6\%, tepung tulang ikan belida $0.4 \%-0.71 \%$ (Kusumaningrum et al., 2016), tepung tulang ikan nila sebesar 5.82\% (Hemung, 2013), tepung tulang ikan patin sebesar 2.09\% (Kaya, 2008) dan tepung tulang ikan tuna yaitu $4.13 \%$ (Trilaksani et al., 2006). Perbedaan kadar lemak yang dihasilkan kemungkinan disebabkan oleh perbedaan jenis ikan dan perbedaan metode yang digunakan. Kadar lemak yang tinggi dapat menyebabkan tepung mempunyai citarasa ikan (fish taste) dan menyebabkan terjadinya oxydative rancidity sebagai akibat oksidasi lemak (Almatsier, 2004). Lemak terdapat pada matriks tulang, khususnya tulang utama ikan, yang terdiri dari banyak sendi tulang. Bahkan lemak tersebut tidak dapat dilepaskan dengan mudah, karena merupakan ikatan kompleks, dan sulit dihilangkan hanya dengan merendam tulang dalam larutan basa (Hemung, 2013). Kadar lemak dalam tulang erat kaitannya dengan lemak tubuh setiap spesies, dan biasanya ikan yang besar dan dewasa mengandung lemak yang tinggi. asam lemak ikan merupakan asam lemak tak jenuh. Asam lemak dalam tepung tulang ikan tersebut pada beberapa spesies ditemukan mengandung asam lemak tak jenuh hampir 80\% (Toppe et al., 2007).

Kadar karbohidrat ditentukan dengan by difference sehingga kadar karbohidrat tergantung dari faktor pengurangannya. Kadar karbohidrat sangar berpengaruh terhadap faktor zat gizi lainnya. Kandungan karbohidrat pada tepung tulang ikan sidat sebesar 6.66\%, nilai ini jauh lebih kecil dibandingkan kadar protein dan lemaknya. Hal yang sama juga diperoleh pada penelitian (Lunda et al., 2019) bahwa kandungan karbohidrat pada tepung tulang ikan peperek hanya $0.0260 \%$. Menurut pendapat (Syahril, 2013), kandungan karbohidrat dalam ikan sangat kecil dibandingkan zat gizi lain. Hal ini diduga karena kadar karbohidrat pada ikan sangat tidak mengandung serat namun dalam bentuk glikogen serta dipengaruhi oleh kondisi ikan yang menyebabkan penurunan kadar glikogen sehingga kadar karbohidrat pada tepung ikan pada penelitian ini cukup rendah. Karbohidrat setelah diabsorbsi oleh sel, glukosa segera diubah menjadi energi atau disimpan dalam tubuh dalam bentuk glikogen. Menurut (Okuzumi \& Fujii, 2000), yang menyatakan bahwa karbohidrat yang ada dalam produk perikanan tidak mengandung serat dan kebanyakan terdapat dalam bentuk glikogen. 
Kadar kalsium yang dihasilkan dari tepung tulang ikan sidat sebesar $18325.13 \mathrm{mg} / 100 \mathrm{~g}$. Kadar kalsium pada penelitian ini lebih tinggi jika dibandingkan kadar kalsium tepung tulang belida berkisar antara 28,25\%-31,31\% (Kusumaningrum et al., 2016), ikan nila yang dilakukan oleh Lakahena et al. (2014) yang hanya berkisar 18,7\%-21,48\%. Kadar kalsium hasil penelitian ini juga lebih tinggi jika dibandingkan dengan kadar kalsium tepung tulang ikan gabus pada penelitian (Cucikodana et al., 2012) yang berkisar antara 16\%-22\%. Perbedaan kandungan kalsium pada tepung tulang ikan, dipengaruhi oleh perbedaan jenis ikan yang digunakan. Navarro (1991) diacu dalam (Martínez et al., 1998) menyebutkan bahwa kandungan mineral pada ikan bergantung pada spesies, jenis kelamin, siklus biologis dan bagian tubuh yang dianalisis. Lebih lanjut (Martínez et al., 1998) menyatakan bahwa faktor ekologis seperti musim, tempat pembesaran, jumlah nutrisi tersedia, suhu dan salinitas air juga dapat mempengaruhi kandungan mineral dalam tubuh ikan.

\section{KESIMPULAN}

Hasil analisis menunjukkan bahwa tepung tulang ikan sidat mengandung kadar abu, protein, dan kalsium yang sangat tinggi dibandingkan tepung tulang ikan lainnya seperti ikan belida, nila, dan patin.

\section{UCAPAN TERIMA KASIH}

Penulis mengucapkan terima kasih kepada Direktorat Riset dan Pengabdian Mayarakat (DRPM) Kementerian Riset Teknologi dan Pendidikan Tinggi Republik Indonesia yang telah memberikan dana melalui hibah Penelitian Dosen Pemula tahun anggaran 2019.Berikan Ucapan Terima Kasih di bagian terpisah di akhir artikel sebelum Referensi;

\section{DAFTAR PUSTAKA}

Almatsier, S. (2004). Prinsip Dasar Ilmu Gizi. PT. Gramedia Pustaka Utama.

Aprilliani, I. S. (2010). Pemanfaatan Tepung Tulang Ikan Patin (Pangasius hypopthalmus) pada Pembuatan Cone Es Krim. Insitut Pertanian Bogor.

Cucikodana, Y., Supriadi, A., \& Purwanto, B. (2012). Pengaruh Perbedaan Suhu Perebusan dan Konsentras $\mathrm{NaOH}$ terhadap Kualitas Bubuk Tulang Ikan Gabus (Channa striata ). FishtecH, 1(1), 91-101.

[FAO], F. and A. O. (2010). Fishery and Aquaculture Statistics 2010. FAO yearbook annuaire anuarin, A-1 \& A-6.

Fitri, A., Anandito, R. B. K., \& Siswanti. (2016). Penggunaan Daging dan Tulang Ikan Bandeng (Chanos chanos) pada Stik Ikan sebagai Makanan Ringan Berkalsium dan Berprotein Tinggi. Jurnal Teknologi Hasil Pertanian, IX(2), 65-77.

Harland, F., \& Oberleas, D. (2001). Effect of Dietary Fiber and Phytat in the Homeostatis and Bioavailability of Mineral (S. AG, Ed.). Library of Congressle. 
Hemung, B.-O. (2013). Properties of Tilapia Bone Powder and Its Calcium Bioavailability Based on Transglutaminase Assay. International Journal of Bioscience, Biochemistry and Bioinformatics, 3(4), 306-309. https://doi.org/10.7763/IJBBB.2013.V3.219

Irawan, A. (1995). Pengolahan Hasil Perikanan. Aneka Solo.

(ISA), I. S. of A. (2002). Analysis of Fish Meal. Inc. Kodiak.

Kaya, A. O. W. (2008). Pemanfaatan Tepung Tulang Ikan Patin (Pangasius sp.) Sebagai Sumber Kalsium Dan Fosfor Dalam Pembuatan Biskuit. 78.

Keputusan Menteri Kelautan dan Perikanan Republik Indonesia No.50/Kepmen-KP/2017 tentang Estimasi Potensi, Jumlah Tangkapan yang Diperbolehkan, dan Tingkat Pemanfaatan Sumberdaya Ikan di Wilayah Pengelolaan Perikanan Negara Republik Indonesia, Pub. L. No. 50/KepmenKP/2017 (2017).

[KKP], K. K. dan Perikanan. (2007). Indonesian Fisheries Statistics Index 2006.

Kusumaningrum, I., Sutono, D., \& Pamungkas, B. F. (2016). Pemanfaatan Tulang Ikan Belida sebagai Tepung Sumber Kalsium dengan Metode Alkali (Recovery of Belida Fish Bone Byproduct as a Rich Calcium Powder by Alcali Method). JPHPI, 19(2), 148-155. https://doi.org/10.17844/jphpi.2016.19.2.148

Li, Z. R., Wang, B., Chi, C. feng, Zhang, Q. H., Gong, Y. dan, Tang, J. J., Luo, H. yu, \& Ding, G. fang. (2013). Isolation and Characterization of Acid Soluble Collagens and Pepsin Soluble Collagens from the Skin and Bone of Spanish Mackerel (Scomberomorous niphonius). Food Hydrocolloids, 31, 103-113. https://doi.org/10.1016/j.foodhyd.2012.10.001

Lunda, N., Ibrahim, M. N., \& Suwarjoyowirayatno. (2019). Pemanfaatan Hasil Samping Pengolahan Ikan Peperek (Leiognathus equulus) menjadi Tepung Ikan. J. Fish Proech, 2(1), 11-17.

Martínez, I., Santaella, M., Ros, G., \& Periago, M. J. (1998). Content and in vitro Availability of Fe, Zn, $\mathrm{Mg}, \mathrm{Ca}$ and $\mathrm{P}$ in Homogenized Fish-based Weaning Foods after Bone Addition. Food Chemistry, 63(3), 299-305. https://doi.org/10.1016/S0308-8146(98)00050-8

Maulida, N. (2005). Pemanfaatan Tepung Tulang Ikan Madidihang (Thunnus albacares) sebagai Suplemen dalam Pembuatan Biskuit (Crackers). Institut Pertanian Bogor.

Mulia. (2004). Kajian Potensi Limbah Tulang Ikan Patin (Pangasius sp) sebagai Alternatif Sumber Daya Kalsium dalam Produk Mie Kering. Institut Pertanian Bogor.

Okuzumi, M., \& Fujii, T. (2000). Nutritinonal and Functional Properties of Squid and Cuttlefish. National Cooperative Association of Squid Processor.

Ramdany, G., Kusumaningrum, I., \& Pamungkas, B. F. (2006). Karakteristik Kimiawi Kerupuk Tulang Ikan Belida (Chitala Sp.). Jurnal Ilmu Perikanan Tropis, 19(2).

Sari, E. N. (2013). Pembuatan Krupuk Ikan Bandeng dengan Substitusi Duri Ikan Bandeng. Universitas Negeri Semarang.

Syahril, M. (2013). Sifat Fisika Kimia Minyak Atsiri. Universitas Hasanuddin.

Tababaka, R. (2004). Pemanfaatan Tepung Tulang Ikan Patin sebagai Bahan Tambahan Kerupuk.pdf. Institut Pertanian Bogor. 
Toppe, J., Albrektsen, S., Hope, B., \& Aksnes, A. (2007). Chemical Composition, Mineral Content and Amino Acid and Lipid Profiles in Bones from Various Fish Species. Comparative Biochemistry and Physiology - B Biochemistry and Molecular Biology, 146(3), 395-401. https://doi.org/10.1016/j.cbpb.2006.11.020

Trilaksani, W., Salamah, E., \& Nabil, M. (2006). Pemanfaatan Limbah Tulang Ikan Tuna (Thunnus Sp.) sebagai Sumber Kalsium dengan Metode Hidrolisis Protein. Jurnal Pengolahan Hasil Perikanan Indonesia, 9(2), 34-45. https://doi.org/10.17844/jphpi.v9i2.983

Wardani, D. P., Liviawaty, E., \& Junianto. (2012). Fortifikasi Tepung Tulang Tuna sebagai Sumber Kalsium terhadap Tingkat Kesukaan Donat. Jurnal Perikanan Dan Kelautan, 3(4), 41-50.

Winarno, F. G. (2008). Kimia Pangan dan Gizi. PT. Gramedia Pustaka Utama. 